\title{
PENGARUH KOMPOS KOTORAN KAMBING TERHADAP KANDUNGAN KARBON DAN FOSFOR TANAH DARI KEBUN KOPI BANGELAN
}

\author{
The Effect of Goat Manure Compost Application on Carbon and \\ Phosphorus Contents of Soil from Bangelan Coffee Plantation
}

\author{
Radifta Adika Suarmaprasetya*, Soemarno \\ Jurusan Tanah, Fakultas Pertanian, Universitas Brawijaya, Jl. Veteran No 1, Malang 65145 \\ *Penulis korespondensi: radifta@gmail.com
}

\begin{abstract}
Inceptisol has a special characteristic, which is low in organic matter. Other chemical problems possessed by Inceptisol include acidic $\mathrm{pH}$, high clay content, and washable surface layers. The compost of goat manure can improve soil chemical properties. The purpose of this study was to determine the effect of the application of goat manure compost at various doses on the carbon and phosphorus content of Inceptisol soil in Bangelan, Malang, East Java. The treatments tested were K1D1 (0-20 cm depth, without compost dose), K1D2 (0-20 cm depth, with compost dose $0.5 \mathrm{~g} 500$ $\mathrm{g}^{-1}$ soil), K1D3 (0-20 depth, with compost dose $1 \mathrm{~g} 500 \mathrm{~g}^{-1}$ soil), K2D1 (20-40 cm depth, without compost dose), K2D2 (20-40 cm depth, with compost dose $0.5 \mathrm{~g} 500 \mathrm{~g}^{-1}$ soil), K2D3 (20-40 cm depth, with compost dose $1 \mathrm{~g} 500 \mathrm{~g}^{-1}$ soil), K3D1 (40-60 cm depth, without compost dose), K3D2 (40-60 $\mathrm{cm}$ depth, with compost dose $0.5 \mathrm{~g} 500 \mathrm{~g}^{-1}$ soil), K3D3 (40-60 cm depth, with compost dose $1 \mathrm{~g} 500$ $\mathrm{g}^{-1}$ of soil). The nine treatments were arranged in a completely randomized factorial design with three replications. The results showed that at a depth of $0-20 \mathrm{~cm}, 20-40 \mathrm{~cm}$, and $40-60 \mathrm{~cm}$ with an additional dose of $1 \mathrm{~g} 500 \mathrm{~g}^{-1}$ of soil was the best dose given into the soil because it had a significant effect on increasing $\mathrm{pH}$, organic $\mathrm{C}$, available $\mathrm{P}$ and total $\mathrm{P}$ in the soil.
\end{abstract}

Keywords : carbon, goat manure compost, Inceptisol, phosphorus

\section{Pendahuluan}

Tanah merupakan salah satu sumber daya alam yang berfungsi sebagai media tumbuh tanaman. Tanah berperan sebagai penyedia nutrisi bagi tanaman lewat unsur hara yang terdapat dalam tanah. Kesuburan tanah dapat mempengaruhi pertumbuhan tanaman. Tanah pada lokasi penelitian berjenis Inceptisol. Inceptisol merupakan tanah yang tersebar luas di Indonesia yaitu, sekitar 20,75 juta ha (37,5\%) dari wilayah daratan Indonesia (Muyassir et al., 2012). Menurut Widodo dan Kusuma (2018), Inceptisol memiliki kandungan bahan organik yang rendah. Permasalahan inceptisol lainnya, yaitu memiliki $\mathrm{pH}$ yang masam, dan lapisan permukaan yang mudah tercuci (Sudirja et al., 2006).Berdasarkan uraian tersebut, maka diperlukan perbaikan terhadap sifat kimia Inceptisol khususnya dalam peningkatan unsur hara dan bahan organik dalam tanah. Salah satu upaya untuk mengatasi permasalahan di Inceptisol adalah dengan penambahan bahan organik. Bahan organik salah satunya dapat berasal dari limbah peternakan kambing. Penambahan bahan organik dapat memperbaiki sifat fisik, kimia, dan biologi tanah. Hasil penelitian Utami et al. (2013), dengan dosis kompos kotoran kambing $6 \mathrm{t} \mathrm{ha}^{-1}$ dapat meningkatkan $\mathrm{pH}$ tanah, KTK, $\mathrm{N}$-tersedia, serta produksi padi dibandingkan dengan perlakuan kontrol.

Kompos kotoran kambing merupakan salah satu pupuk organik yang ramah lingkungan yang berbahan dasar dari kotoran 


\section{Jurnal Tanah dan Sumberdaya Lahan Vol 8 No 2: 505-514, 2021 e-ISSN:2549-9793, doi: 10.21776/ub.jts1.2021.008.2.21}

hewan kambing. Menurut hasil analisis yang telah dilakukan, pupuk kompos kotoran kambing ini memiliki kandungan unsur hara dengan $\mathrm{N}$ sebesar 2,5\%, unsur hara $\mathrm{P}$ sebesar $1,48 \%$, dan C organik sebesar 15,39\%. Selain memiliki unsur hara yang dapat menunjang pertumbuhan tanaman, pemberian bahan organik kedalam tanah juga dapat meningkatkan sifat kimia tanah. Menurut Setyorini et al. (2006), pemberian bahan organik dapat meningkatkan kapasitas tukar kation atau kandungan hara, penting untuk daya pulih tanah akibat perubahan $\mathrm{pH}$ tanah dan menyimpan cadangan hara penting dalam tanah.

Tujuan penelitian ini adalah untuk mempelajari pengaruh aplikasi kompos kotoran kambing terhadap ketersediaan karbon dan fosfor tanah dari kebun Bangelan, Malang.

\section{Bahan dan Metode}

Penelitian dilakukan pada bulan Maret 2020 hingga Juli 2020. Penelitian inkubasi tanah dilakukan pada laboratorium Lingkungan Fakultas Pertanian Brawijaya dan Analisis kimia tanah dilakukan di Laboratorium Kimia Jurusan Tanah Fakultas Pertanian Universitas Brawijaya Malang. Pengambilan Sampel Tanah dilakukan di Kebun Bangelan, Kecamatan Wonosari, Kabupaten Malang. Penelitian ini menggunakan Rancangan Acak Lengkap Faktorial dengan 9 perlakuan dan 3 ulangan. Perlakuan terdiri atas K1D1 (kedalaman 0-20 cm tanpa dosis kompos), K1D2 (kedalaman 0-20 cm dengan dosis kompos 0,5 g $500 \mathrm{~g}^{-1}$ tanah), K1D3 (kedalaman 0-20 $\mathrm{cm}$ dengan dosis kompos $1 \mathrm{~g}$ $500 \mathrm{~g}^{-1}$ tanah), K2D1 (kedalaman $20-40 \mathrm{~cm}$ tanpa dosis kompos), K2D2 (kedalaman 20-40 $\mathrm{cm}$ dengan dosis kompos $0,5 \mathrm{~g} 500 \mathrm{~g}^{-1}$ tanah), K2D3 (Kedalaman 20-40 cm dengan dosis

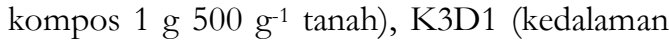
40-60 cm tanpa dosis kompos), K3D2 (kedalaman 40-60 cm dengan dosis kompos 0,5 g $500 \mathrm{~g}^{-1}$ tanah), K3D3 (Kedalaman 40-60 cm dengan dosis kompos $1 \mathrm{~g} 500 \mathrm{~g}^{-1}$ tanah). Tanah inkubasi menggunakan polibag ukuran 7,5 x 15 $\mathrm{cm}$. Pengamatan penelitian meliputi $\mathrm{pH}$ aktual, $\mathrm{pH}$ potensial (0, 2, 16, 18 Minggu Setelah Inkubasi) (MSI), sedangkan pengamatan $\mathrm{C}$ organik, $\mathrm{P}$ tersedia, dan $\mathrm{P}$ total (0 dan $18 \mathrm{MSI})$.

\section{Hasil dan Pembahasan}

\section{pH tanah}

Derajat kemasaman tanah $(\mathrm{pH})$ tanah dapat dikelompokkan menjadi dua, yaitu $\mathrm{pH}$ aktual ( $\mathrm{pH} \mathrm{H}_{2} \mathrm{O}$ ) dan $\mathrm{pH}$ potensial ( $\mathrm{pH} \mathrm{KCl}$. Menurut Hanafiah (2012), reaksi tanah ( $\mathrm{pH}$ tanah) sangat penting untuk diketahui sebab dari data $\mathrm{pH}$ tanah dapat diketahui indikator ketersediaan unsur hara dan adanya unsur beracun dalam tanah. $\mathrm{pH}$ tanah dapat menunjukkan tingkat kemasam tanah atau alkalinitas tanah. Hasil analisis ragam dapat diketahui perlakuan dosis kompos dan kedalaman contoh tanah berpengaruh sangat nyata terhadap nilai $\mathrm{pH}$ tanah pada 18 MSI (Tabel 1). Namun, tidak terdapat interaksi diantaranya. Nilai $\mathrm{pH}$ tanah pada perlakuan tanah dengan penambahan kompos kotoran kambing pada seluruh perlakuan mengalami peningkatan di setiap waktu pengamatan yang dilakukan di $0,2,16$, dan 18 MSI.

Tabel 1. Pengaruh dosis kompos terhadap $\mathrm{pH}$ tanah.

\begin{tabular}{|c|c|c|c|c|c|c|c|c|c|c|c|c|}
\hline \multirow{4}{*}{$\begin{array}{c}\text { Dosis } \\
\text { Kompos }\end{array}$} & \multicolumn{12}{|c|}{ Waktu Pengamatan } \\
\hline & \multicolumn{3}{|c|}{0 MSI } & \multicolumn{3}{|c|}{2 MSI } & \multicolumn{3}{|c|}{$16 \mathrm{MSI}$} & \multicolumn{3}{|c|}{18 MSI } \\
\hline & $\mathrm{pH}$ & $\mathrm{pH}$ & $\Delta \mathrm{pH}$ & $\mathrm{pH}$ & $\mathrm{pH}$ & $\Delta \mathrm{pH}$ & $\mathrm{pH}$ & $\mathrm{pH}$ & $\Delta \mathrm{pH}$ & $\mathrm{pH}$ & $\mathrm{pH}$ & $\Delta \mathrm{pH}$ \\
\hline & $\mathrm{H}_{2} \mathrm{O}$ & $\mathrm{KCl}$ & & $\mathrm{H}_{2} \mathrm{O}$ & $\mathrm{KCl}$ & & $\mathrm{H}_{2} \mathrm{O}$ & $\mathrm{KCl}$ & & $\mathrm{H}_{2} \mathrm{O}$ & $\mathrm{KCl}$ & \\
\hline $\begin{array}{c}0 \mathrm{~g} 500 \mathrm{~g} \\
{ }^{1} \text { tanah }\end{array}$ & $5,16 \mathrm{a}$ & 4,76 & $-0,40$ & $4,92 \mathrm{a}$ & 4,63 & $-0,29$ & $5,01 \mathrm{a}$ & 4,65 & $-0,35$ & $5,04 a$ & 4,66 & $-0,39$ \\
\hline 0,5 g 500 & $4,91 \mathrm{~b}$ & 4,77 & $-0,14$ & $4,92 \mathrm{a}$ & 4,66 & $-0,26$ & $5,06 \mathrm{~b}$ & 4,71 & $-0,35$ & $5,09 \mathrm{~b}$ & 4,71 & $-0,38$ \\
\hline $\mathrm{g}^{-1}$ tanah & & & & & & & & & & & & \\
\hline $\begin{array}{c}1 \mathrm{~g} 500 \mathrm{~g} \\
1 \text { tanah }\end{array}$ & $4,88 \mathrm{~b}$ & 4,80 & $-0,09$ & $4,94 \mathrm{a}$ & 4,69 & $-0,25$ & $5,09 \mathrm{c}$ & 4,72 & $-0,37$ & $5,12 \mathrm{c}$ & 4,74 & $-0,38$ \\
\hline
\end{tabular}

Keterangan : Angka pada kolom yang sama yang diikuti huruf sama menunjukkan tidak berbeda nyata pada Uji BNT 5\%. MSI: minggu selama inkubasi. 


\section{Jurnal Tanah dan Sumberdaya Lahan Vol 8 No 2: 505-514, 2021 e-ISSN:2549-9793, doi: 10.21776/ub.jts1.2021.008.2.21}

Awodun (2007) menyatakan bahwa penambahan kompos kotoran kambing dengan dosis $8 \mathrm{t} \mathrm{ha}^{-1}$ dapat meningkatkan $\mathrm{pH}$ tanah. Menurut Mupondi et al. (2006), peningkatan pH tanah yang terjadi karna penambahan kompos kotoran kambing disebabkan oleh proses amonifikasi yaitu protein dan asam amino terdegradasi menjadi ammonia. Kompos kotoran kambing akan menambahkan nitrogen sebagai $\mathrm{NH}_{4}{ }^{+}$dan kemudian melepaskan ion $\mathrm{H}^{+}$ melalui proses oksidasi, sehingga meningkatkan pH H$H_{2} \mathrm{O}$ tanah (Rosmarkan dan Yuwono, 2002).

Reaksi $\mathrm{pH} \mathrm{KCl}$ pada semua parameter dan semua waktu inkubasi menunjukkan nilai yang lebih rendah dari $\mathrm{pH} \mathrm{H} \mathrm{H}_{2} \mathrm{O}$. Amran et al. (2015), menyatakan bahwa nilai $\mathrm{pH}$ menunjukkan konsentrasi ion $\mathrm{H}^{+}$di dalam tanah yang dinyatakan sebagai $-\log \left[\mathrm{H}^{+}\right]$. Konsentrasi $\mathrm{H}+$ yang diekstrak dengan air menyatakan kemasaman aktif (aktual). Pengekstrak KCl 1N menyatakan kemasaman cadangan (potensial). Lebih lanjut Amran et al. (2015), menjelaskan bahwa $\mathrm{pH}$ aktual adalah $\mathrm{pH}$ yang menunjukkan konsentrasi $\mathrm{H}^{+}$di dalam larutan tanah sesuai dengan kondisi aslinya, sedangkan $\mathrm{pH} \mathrm{KCl}$ atau yang disebut $\mathrm{pH}$ tanah potensial adalah $\mathrm{pH}$ yang menunjukkan nilai $\mathrm{pH}$ tanah setelah $\mathrm{H}^{+}$di dalam jerapan tanah yang didesak keluar dan digantikan oleh kation $\mathrm{K}^{+} . \Delta \mathrm{pH}$ merupakan selisih antara $\mathrm{pH}$ potensial dengan $\mathrm{pH}$ aktual. Pada Tabel 2 ditunjukan bahwa nilai $\Delta \mathrm{pH}$ pada semua parameter menunjukkan nilai negatif. $\mathrm{Hal}$ ini sesuai dengan pernyataan Masjkur (2007), menyatakan bahwa umumnya nilai $\mathrm{pH} \mathrm{KCl}$ pada seri tanah yang ada selalu lebih rendah dari $\mathrm{pH}$ $\mathrm{H}_{2} \mathrm{O}$ dan memberikan $\Delta \mathrm{pH}$ yang negatif. Hal ini berarti bahwa tanah tersebut memiliki muatan netto yang negatif. Muatan negatif tanah tersebut ditempati oleh basa-basa yang dapat ditukar.

Tabel 2. Pengaruh Kedalaman terhadap pH tanah.

\begin{tabular}{|c|c|c|c|c|c|c|c|c|c|c|c|c|}
\hline \multirow{3}{*}{$\begin{array}{l}\text { Contoh } \\
\text { tanah } \\
\text { diambil } \\
\text { dari } \\
\text { kedalam- } \\
\text { an }\end{array}$} & \multicolumn{12}{|c|}{ Waktu Pengamatan } \\
\hline & \multicolumn{3}{|c|}{0 MSI } & \multicolumn{3}{|c|}{2 MSI } & \multicolumn{3}{|c|}{$16 \mathrm{MSI}$} & \multicolumn{3}{|c|}{18 MSI } \\
\hline & $\begin{array}{c}\mathrm{pH} \\
\mathrm{H}_{2} \mathrm{O}\end{array}$ & $\begin{array}{l}\mathrm{pH} \\
\mathrm{KCl}\end{array}$ & $\Delta \mathrm{pH}$ & $\begin{array}{c}\mathrm{pH} \\
\mathrm{H}_{2} \mathrm{O}\end{array}$ & $\begin{array}{l}\mathrm{pH} \\
\mathrm{KCl}\end{array}$ & $\Delta \mathrm{pH}$ & $\begin{array}{c}\mathrm{pH} \\
\mathrm{H}_{2} \mathrm{O}\end{array}$ & $\begin{array}{l}\mathrm{pH} \\
\mathrm{KCl}\end{array}$ & $\Delta \mathrm{pH}$ & $\begin{array}{c}\mathrm{pH} \\
\mathrm{H}_{2} \mathrm{O}\end{array}$ & $\begin{array}{l}\mathrm{pH} \\
\mathrm{KCl}\end{array}$ & $\Delta \mathrm{pH}$ \\
\hline $0-20 \mathrm{~cm}$ & $5,44 \mathrm{a}$ & 4,74 & $-0,69$ & $4,92 \mathrm{a}$ & 4,55 & $-0,37$ & $4,95 \mathrm{a}$ & 4,56 & $-0,39$ & $4,90 \mathrm{a}$ & 4,58 & $-0,32$ \\
\hline $20-40 \mathrm{~cm}$ & $5,04 \mathrm{ab}$ & 4,73 & $-0,31$ & $4,81 \mathrm{~b}$ & 4,65 & $-0,17$ & $4,99 \mathrm{~b}$ & 4,67 & $-0,32$ & $5,08 \mathrm{~b}$ & 4,67 & $-0,41$ \\
\hline $40-60 \mathrm{~cm}$ & $5,00 \mathrm{~b}$ & 4,80 & $-0,19$ & $5,03 c$ & 4,68 & $-0,35$ & $5,09 \mathrm{c}$ & 4,73 & $-0,35$ & $5,15 c$ & 4,72 & $-0,42$ \\
\hline
\end{tabular}

Keterangan : Angka pada kolom yang sama yang diikuti huruf sama menunjukkan tidak berbeda nyata pada Uji BNT 5\%. MSI: minggu selama inkubasi.

Bertambahnya kedalaman tanah dapat juga menjadikan $\mathrm{pH}$ tanah $\mathrm{H}_{2} \mathrm{O}$ semakin rendah. Data pada Tabel 2 menunjukkan pengamatan 0 MSI yang telah dilakukan terlihat bahwa seiring bertambahnya kedalaman tanah juga menurunkan $\mathrm{pH} \mathrm{H}_{2} \mathrm{O}$ tanah. Hal ini karena bahan induk Inceptisol yang bersifat masam. Suharta (2007) menyatakan bahwa semakin bertambahnya kedalaman tanah reaksi tanah $(\mathrm{pH})$ Inceptisol semakin masam hal tersebut karena Inceptisol terbentuk dari batuan sedimen yang bersifat masam. Sifat masam pada batuan induk tersebut mengakibatkan reaksi tanah yang masam, karena kejenuhan alumunium (Al) yang sangat tinggi dan nilainya meningkat seiring bertambahnya kedalam tanah. Menurut Hong (2008), nilai $\mathrm{pH}$ tanah sangat berpengaruh terhadap $\mathrm{H}^{+}$dan $\mathrm{Al}^{3+}$ yang sangat berperan dalam kemasaman tanah.

\section{C organik}

Hasil analisis ragam yang telah dilakukan perlakuan dosis kompos kotoran kambing berpengaruh sangat nyata terhadap peningkatan kandungan $\mathrm{C}$ organik pada tanah. Dari Tabel 3 dapat dilihat bahwa semakin bertambahnya dosis yang di berikan semakin bertambahnya pula jumlah $C$ organik dalam tanah. Pada 


\section{Jurnal Tanah dan Sumberdaya Lahan Vol 8 No 2: 505-514, 2021 e-ISSN:2549-9793, doi: 10.21776/ub.jts1.2021.008.2.21}

pengamatan 18 MSI nilai $\mathrm{C}$ organik tertinggi terdapat pada perlakuan dosis $1 \mathrm{~g}^{2} 50 \mathrm{~g} \mathrm{~g}^{-1}$ tanah $(1,2)$, dan nilai $\mathrm{C}$ organik terendah terdapat pada perlakuan dosis 0 g $500 \mathrm{~g}^{-1}$ tanah $(0,95)$. Peningkatan jumlah C organik dalam tanah ini sesuai dengan pernyataan Putra dan Nuraini (2017), yang menyatakan bahwa penambahan bahan organik pada tanah yang masam akan mempercepat pembebasan karbon sehingga kadar $\mathrm{C}$ organik dalam tanah akan meningkat.
Kandungan $\mathrm{C}$ organik pada semua perlakuan dari 0 MSI menuju 18 MSI mengalami penurunan pada semua perlakuan. Menurut Aziz et al. (2012), penurunan kandungan C organik ini disebabkan oleh aktivitas mikroorganisme tanah yang memanfaatkan senyawa karbon untuk pembentukan sel-sel tubuhnya dan sebagian lagi dibebaskan dalam bentuk $\mathrm{CO}_{2}$ selama proses dekomposisi sehingga kadar $\mathrm{C}$ organik menjadi berkurang.

Tabel 3. Pengaruh dosis kompos terhadap C organik tanah.

\begin{tabular}{cccc}
\hline Dosis Kompos & \multicolumn{3}{c}{ C organik (\%) } \\
\cline { 2 - 4 } & $\mathbf{0 ~ M S I}$ & $\mathbf{1 8}$ MSI & $\begin{array}{c}\text { Perubahan kandungan C } \\
\text { organik : 18MSI- 0MSI }\end{array}$ \\
\hline $0 \mathrm{~g} 500 \mathrm{~g}^{-1}$ tanah & $1,64 \mathrm{a}$ & $0,95 \mathrm{a}$ & 0,69 \\
$0,5 \mathrm{~g} 500 \mathrm{~g}^{-1}$ tanah & $1,76 \mathrm{ab}$ & $1,07 \mathrm{~b}$ & 0,69 \\
$1 \mathrm{~g} 500 \mathrm{~g}^{-1}$ tanah & $1,94 \mathrm{~b}$ & $1,2 \mathrm{c}$ & 0,72 \\
\hline
\end{tabular}

Keterangan : Angka pada kolom yang sama yang diikuti huruf sama menunjukkan tidak berbeda nyata pada Uji BNT 5\%. MSI: minggu selama inkubasi.

Menurut Pratiwi et al. (2013), juga menyatakan kandungan $\mathrm{C}$ organik akan berkurang akibat pelepasan karbondioksida dan dekomposisi bahan organik selama inkubasi tanah. Selain itu penurunan kandungan $\mathrm{C}$ organik dapat disebabkan oleh perlakuan bahan organik. menurut Irawan et al. (2016), menjelaskan bahwa penurunan $\mathrm{C}$ organik dapat disebabkan karena bahan organik yang diberikan mempengaruhi perombakan bahan organik menjadi senyawa sederhana (anorganik) sehingga kadar C organik menurun dalam tanah.

Tabel 4. Pengaruh kedalaman terhadap C organik tanah.

\begin{tabular}{ccc}
\hline $\begin{array}{c}\text { Contoh tanah } \\
\text { diambil dari } \\
\text { kedalaman }\end{array}$ & \multicolumn{2}{c}{ C organik (\%) } \\
\cline { 2 - 3 } & 0 MSI & $\mathbf{1 8}$ MSI \\
\hline $0-20 \mathrm{~cm}$ & $1,983 \mathrm{~b}$ & $1,52 \mathrm{~b}$ \\
$20-40 \mathrm{~cm}$ & $1,645 \mathrm{a}$ & $0,89 \mathrm{a}$ \\
$40-60 \mathrm{~cm}$ & $1,712 \mathrm{a}$ & $0,83 \mathrm{a}$ \\
\hline
\end{tabular}

Keterangan : Angka pada kolom yang sama yang diikuti huruf sama menunjukkan tidak berbeda nyata pada Uji BNT 5\%. MSI: minggu selama inkubasi.

Dari hasil analisis ragam diketahui bahwa kedalaman tanah berpengaruh sangat nyata terhadap penurunan kandungan $\mathrm{C}$ organik pada 18 MSI, yang artinya setiap penurunan kedalaman tanah akan mengurangi nilai kandungan $\mathrm{C}$ organik pada tanah. Data nilai kandungan $\mathrm{C}$ organik pada setiap kedalaman ditampilkan pada (Tabel 4). Semakin bertambahnya kedalaman juga menurunkan kandungan $\mathrm{C}$ organik pada dalam tanah. Pada (Tabel 4), hasil analisis diperlihatkan semakin bertambahnya kedalaman juga akan berkuranganya kandungan $C$ organik pada tanah tersebut. Menurut Sipahutar et al. (2014), menyatakan bahwa kandungan $\mathrm{C}$ organik yang cenderung menurun pada seiring bertambahnya kedalaman dapat disebabkan seresah dan bahan organik yang jatuh ke permukaan tanah. Hal ini sejalan dengan kondisi pengambilan sampel penelitian dimana banyaknya seresah daun terutama kopi yang berguguran di atas tanah. Damanik, et al. (2010) menjelaskan bahwa bahan organik tersebut terakumulasi pada topsoil (tanah bagian atas) dan sebagian tercuci ke lapisan yang lebih dalam. Ichriani et al. (2013) menyatakan bahwa keberadaan bahan organik pada lapisan bawah diakibatkan karena adanya pengolahan tanah, pengangkutan oleh organisme tanah dan pencucian bahan organik.

\section{P-tersedia}

Hasil analisis ragam yang telah dilakukan menunjukkan bahwa perlakuan dosis kompos kotoran kambing dan kedalaman tanah 


\section{Jurnal Tanah dan Sumberdaya Lahan Vol 8 No 2: 505-514, 2021 \\ e-ISSN:2549-9793, doi: 10.21776/ub.jts1.2021.008.2.21}

berpengaruh nyata dalam peningkatan kandungan $\mathrm{P}$ tersedia dalam tanah namun tidak ada interaksi diantara keduanya.

Tabel 5. Pengaruh penambahan dosis kompos terhadap P tersedia dalam tanah.

\begin{tabular}{|c|c|c|c|}
\hline \multirow{2}{*}{$\begin{array}{c}\text { Dosis } \\
\text { Kompos }\end{array}$} & \multicolumn{3}{|c|}{ P tersedia $(\mathrm{ppm})$} \\
\hline & $\begin{array}{c}0 \\
\text { MSI }\end{array}$ & $\begin{array}{c}18 \\
\text { MSI }\end{array}$ & $\begin{array}{c}\text { Perubahan } \\
\text { kandungan } \\
\text { P tersedia : } \\
18 \mathrm{MSI}- \\
0 \mathrm{MSI}\end{array}$ \\
\hline $\begin{array}{c}0 \mathrm{~g} 500 \mathrm{~g}^{-1} \\
\text { tanah }\end{array}$ & $2,36 \mathrm{a}$ & $1,28 \mathrm{a}$ & 1,08 \\
\hline $\begin{array}{l}0,5 \text { g } 500 \\
\mathrm{~g}^{-1} \text { tanah }\end{array}$ & $2,94 \mathrm{ab}$ & $1,97 \mathrm{ab}$ & 0,97 \\
\hline $\begin{array}{c}1 \mathrm{~g} 500 \mathrm{~g}^{-1} \\
\text { tanah }\end{array}$ & $3,38 \mathrm{~b}$ & $2,83 \mathrm{~b}$ & 0,55 \\
\hline
\end{tabular}

Keterangan : Angka pada kolom yang sama yang diikuti huruf sama menunjukkan tidak berbeda nyata pada Uji BNT 5\%. MSI: minggu selama inkubasi.

Pada Tabel 5 dapat terlihat bahwa penambahan dosis kompos kotoran kambing berpengaruh terhadap nilai $\mathrm{P}$ tersedia di dalam tanah. Semakin bertambahnya jumlah dosis yang diberikan akan meningkatan nilai $\mathrm{P}$ tersedia dalam tanah. Hal ini dipengaruhi sumber bahan organik yang dimasukkan ke dalam tanah. Menurut Muklhis et al. (2011), bahan organik merupakan salah satu sumber fosfor dalam tanah serta merupakan sumber hara N, P dan S. Yang berarti semakin banyak dosis kompos kotoran kambing yang diberikan ke dalam tanah akan semakin banyak hara yang diberikan ke dalam tanah tersebut. Pada (Tabel 5) diperlihatkan dalam 0 MSI menuju 18 MSI kandungan $\mathrm{P}$ tersedia dalam semua perlakuan menunjukkan penurunan. Hal ini dapat disebabkan karna proses dekomposisi dari bahan organik. Karnilawati et al. (2013), menjelaskan hasil dekomposisi dari bahan organik dapat berpengaruh dalam terhadap kelarutan P di dalam tanah, apabila laju dekomposisi bahan organik menurun akan berakibat pula dalam penurunan kadar $\mathrm{P}$ tersedia dalam tanah.

Pada Tabel 6 dapat dilihat kandungan P tersedia dalam semua perlakuan termasuk dalam kriteria rendah hingga sangat rendah. Pada lapisan kedalaman $1(0-20 \mathrm{~cm})$ merupakan nilai tertinggi yang didapat dibandingkan dengan kedalaman lainnya. Menurunnya ketersediaan $\mathrm{P}$ pada kedalaman tanah yang semakin dalam dapat disebabkan oleh pengaruh kedalaman tanah. Hal ini turut didukung oleh hasil penelitian Sipahutar et al. (2014), kadar P Tersedia pada Humitropepts Kecamatan Lintong Nihuta cenderung mengalami penurunan seiring dengan ketinggian tempat dan kedalaman. Penurunan kadar $\mathrm{P}$ tersedia karena proses pelapukan yang semakin dalam tanah semakin rendahnya proses pelapukan yang berakibat kadar P tersedia dalam tanah semakin rendah.

Tabel 6. Pengaruh kedalaman terhadap $\mathrm{P}$ tersedia dalam tanah.

\begin{tabular}{ccc}
\hline Contoh tanah & \multicolumn{2}{c}{ P-tersedia (ppm) } \\
\cline { 2 - 3 } $\begin{array}{c}\text { diambil dari } \\
\text { kedalaman }\end{array}$ & $\mathbf{0 ~ M S I}$ & $\mathbf{1 8}$ MSI \\
\hline $0-20 \mathrm{~cm}$ & $5,88 \mathrm{~b}$ & $4,28 \mathrm{~b}$ \\
$20-40 \mathrm{~cm}$ & $1,54 \mathrm{a}$ & $0,97 \mathrm{a}$ \\
$40-60 \mathrm{~cm}$ & $1,26 \mathrm{a}$ & $0,84 \mathrm{a}$ \\
\hline
\end{tabular}

Keterangan : Angka pada kolom yang sama yang diikuti huruf sama menunjukkan tidak berbeda nyata pada Uji BNT 5\%. MSI: minggu selama inkubasi.

\section{$P$ total}

Fosfor (P) merupakan salah satu unsur hara makro yang dibutuhkan oleh tanaman. Hasil analisis ragam yang telah dilakukan menunjukkan bahwa perlakuan dosis kompos kotoran kambing dan kedalaman tanah berpengaruh nyata dalam peningkatan kandungan $\mathrm{P}$ total dalam tanah namun tidak ada interaksi diantara keduanya. Nilai P total dalam semua perlakuan masuk dalam rentang sangat tinggi hingga rendah (Tabel 7). Nilai $\mathrm{P}$ total tertinggi didapatkan pada perlakuan dosis $1 \mathrm{~g}$ $500 \mathrm{~g}^{-1}$ dan nilai terendah pada perlakuan dosis $0 \mathrm{~g} 500 \mathrm{~g}^{-1}$. Nilai kandungan P total semakin naik apabila dosis kompos kotoran kambing yang diberikan semakin banyak. Kenaikan nilai kandungan $\mathrm{P}$ total ini disebabkan karna penmbahan bahan organik kedalam tanah, hal ini sesuai dengan pernyataan Irawan et al. (2016), penambahan kompos kotoran kedalam tanah dapat menyumbang hara $\mathrm{P}$ dan melepaskan $\mathrm{P}$ yang terikat oleh fraksi amorf dalam tanah. Hakim et al. (1986), menyatakan bahwa bahan organik dapat mempengaruhi ketersediaan fosfat melalui dekomposisi yang menghasilkan 


\section{Jurnal Tanah dan Sumberdaya Lahan Vol 8 No 2: 505-514, 2021 e-ISSN:2549-9793, doi: 10.21776/ub.jts1.2021.008.2.21}

asam-asam organik yang berpengaruh langsung meningkatkan jumlah $\mathrm{P}$ total dalam tanah.

Tabel 7. Pengaruh penambahan dosis kompos terhadap P total tanah.

\begin{tabular}{|c|c|c|c|}
\hline \multirow{2}{*}{$\begin{array}{c}\text { Dosis } \\
\text { Kompos }\end{array}$} & \multicolumn{3}{|c|}{$P$ total $(\mathrm{ppm})$} \\
\hline & $\begin{array}{c}0 \\
\text { MSI }\end{array}$ & $\begin{array}{c}18 \\
\text { MSI }\end{array}$ & $\begin{array}{c}\text { Perubahan } \\
\text { kandungan } \\
\text { P total : } 18 \\
\text { MSI- 0 MSI }\end{array}$ \\
\hline $\begin{array}{c}0 \text { g } 500 \\
g^{-1} \text { tanah }\end{array}$ & $350,5 \mathrm{a}$ & 335,9 a & $-14,6$ \\
\hline $\begin{array}{l}0,5 \text { g } 500 \\
g^{-1} \text { tanah }\end{array}$ & $365,1 \mathrm{ab}$ & $377 \mathrm{ab}$ & 11,9 \\
\hline $\begin{array}{c}1 \mathrm{~g} 500 \\
\mathrm{~g}^{-1} \text { tanah }\end{array}$ & $414,6 \mathrm{~b}$ & $420,3 \mathrm{~b}$ & 5,7 \\
\hline
\end{tabular}

Keterangan : Angka pada kolom yang sama yang diikuti huruf sama menunjukkan tidak berbeda nyata pada Uji BNT 5\%. MSI: minggu selama inkubasi.

Pada Tabel 8 dapat dilihat bahwa kedalaman tanah berpengaruh terhadap nilai $\mathrm{P}$ total tanah. Pada 18 MSI kedalaman 0-20 cm merupakan kedalaman dengan nilai P total tertinggi $(564,7)$, sedangkan kedalaman 40-60 cm memiliki nilai P total terendah (234,1). Sipahutar et al. (2014) menyatakan bahwa kedalaman tanah dan ketinggian tempat merupakan beberapa faktor yang mempengaruhi besar kecilnya nilai aspek kesuburan. Berkurangnya nilai hara pada kedalaman tanah yang semakin dalam karena pencucian (leaching).

Tabel 8. Pengaruh kedalaman terhadap $\mathrm{P}$ total tanah.

\begin{tabular}{ccc}
\hline Contoh tanah & \multicolumn{2}{c}{ P total (ppm) } \\
\cline { 2 - 3 } diambil dari & 0 MSI & 18 MSI \\
kedalaman & & \\
\hline $0-20 \mathrm{~cm}$ & $514,0 \mathrm{c}$ & $564,7 \mathrm{c}$ \\
$20-40 \mathrm{~cm}$ & $343,3 \mathrm{~b}$ & $334,4 \mathrm{~b}$ \\
$40-60 \mathrm{~cm}$ & $272,9 \mathrm{a}$ & $234,1 \mathrm{a}$ \\
\hline
\end{tabular}

Keterangan: Angka pada kolom yang sama yang diikuti huruf sama menunjukkan tidak berbeda nyata pada Uji BNT 5\%. MSI: minggu selama inkubasi.

\section{Rasio C:P}

Rasio C:P merupakan perbandingan antara C organik dengan P tanah. Dari nilai C:P ini kita dapat melihat kecepatan pelapukan dari bahan organik. Hasil analisis ragam menunjukkan bahwa perlakuan kedalaman berpengaruh sangat nyata terhadap perubahan nisbah C:P total pada 18 MSI. Perlakuan dosis tidak berpengaruh nyata terhadap perubahan nisbah C:P total. Selain itu, tidak terdapat interaksi diantara kedua perlakuan tersebut. Hasil pada Tabel 9 menunjukkan nilai rasio C:P total dalam tanah pada seluruh perlakuan. Pada perlakuan kedalaman $1(0-20 \mathrm{~cm})$, memiliki nilai rasio C:P terkecil dan nilai rasio $\mathrm{C}: \mathrm{P}$ terbesar didapatkan pada kedalaman $3(40-60 \mathrm{~cm})$. Tinggi rendahnya nilai C:P juga dipengaruhi oleh nilai $\mathrm{C}$ organik. Menurut Sismiyanti et al. (2018), tinggi rendahnya total karbon akan mempengaruhi laju dekomposisi semakin tinggi total kandungan Ctotal semakin lama laju dekomposisinya dan juga sebaliknya semakin rendah kandungan $\mathrm{C}$ total akan memungkinkan proses dekomposisi yang lebih cepat. Tinggi rendahnya nilai C:P ini juga akan mempengaruhi laju dekomposisi, semakin rendah nilai C:P semakin cepat proses mineralisasi dan juga sebaliknya apabila nilai C:P semakin tinggi akan memungkinkan proses mineralisasi yang semakin lama.

Tabel 9. Pengaruh kedalaman terhadap C:P total tanah.

\begin{tabular}{ccc}
\hline Contoh tanah & \multicolumn{2}{c}{ C:P total } \\
\cline { 2 - 3 } $\begin{array}{c}\text { diambil dari } \\
\text { kedalaman }\end{array}$ & 0 MSI & 18 MSI \\
\hline $0-20 \mathrm{~cm}$ & $38,67 \mathrm{a}$ & $27,35 \mathrm{a}$ \\
$20-40 \mathrm{~cm}$ & $48,47 \mathrm{~b}$ & $26,74 \mathrm{a}$ \\
$40-60 \mathrm{~cm}$ & $64,02 \mathrm{c}$ & $36,25 \mathrm{~b}$ \\
\hline
\end{tabular}

Keterangan : Angka pada kolom yang sama yang diikuti huruf sama menunjukkan tidak berbeda nyata pada Uji BNT 5\%. MSI: minggu selama inkubasi.

Keberadaan unsur hara tanah di Kebun Bangelan memiliki nilai yang bervariasi pada setiap kedalamannya. Lapisan $0-20 \mathrm{~cm}$ merupakan lapisan dengan nilai kandungan bahan organik (C organik), $\mathrm{P}$ tersedia, dan $\mathrm{P}$ total terbanyak dibandingkan dengan lapisan 20$40 \mathrm{~cm}$ dan 40-60 cm. Perubahan nilai kandungan tanah ini disebabkan banyak faktor salah satunya merupakan leaching atau pencucian. Pada lapisan 0-20 cm merupakan lapisan bagian atas (top soil) memiliki bahan organik dan seresah yang melimpah pada tanah karena kebiasaan petani yang membiarkan 


\section{Jurnal Tanah dan Sumberdaya Lahan Vol 8 No 2: 505-514, 2021 e-ISSN:2549-9793, doi: 10.21776/ub.jts1.2021.008.2.21}

seresah jatuh lalu terdekomposisi pada tanah bagian atas, hal ini menyebakan pada lapisan tersebut mendapatkan suplai bahan organik terus menerus yang mengakibatkan pada lapisan tersebut memiliki nilai kandungan $\mathrm{C}$ dan $\mathrm{P}$ yang tinggi. Ichriani et al. (2013) menyatakan bahwa pada lapisan atas tanah selalu mendapat suplai bahan organik yang terus menerus. Keberadaan bahan organik pada lapisan bawah diakibatkan karena adanya pengolahan tanah, pengangkutan oleh organisme tanah dan pencucian bahan organik.

Derajat kemasaman tanah ( $\mathrm{pH}$ tanah) pada Kebun Bangelan tergolong masam pada semua kedalaman. Setiap bertambahnya kedalaman akan diikuti oleh berkurangnya nilai $\mathrm{pH}$ aktual tanah yang menandakan bahwa bertambahnya kedalaman tanah tanah semakin bersifat masam. Hal tersebut karena, Inceptisol terbentuk dari batuan sedimen yang bersifat masam. Suharta (2007) menyatakan bahwa sifat masam pada batuan induk tersebut mengakibatkan reaksi tanah yang masam, karena kejenuhan alumunium ( $\mathrm{Al}$ ) yang sangat tinggi dan nilainya meningkat seiring bertambahnya kedalam tanah. Kompos kotoran kambing berperan dalam peningkatan nilai kandungan $\mathrm{C}$ organik, $\mathrm{P}$ tersedia, dan $\mathrm{P}$ total tanah selain itu, kompos kotoran kambing dapat juga meningkatkan $\mathrm{pH}$ tanah. Penambahan kompos kotoran kambing mampu meningkatkan nilai $\mathrm{pH}, \mathrm{C}$ organik, $\mathrm{P}$ tersedia, dan $\mathrm{P}$ total dalam tanah dibandingkan tanpa penambahan kompos kotoran kambing. Semakin bertambahnya dosis yang diberikan juga akan mempengaruhi nilai kandungan $\mathrm{C}$ dan P dalam tanah. Dosis $1 \mathrm{~g}^{2} 00 \mathrm{~g}^{-1}$ tanah mampu meningkatkan nilai kandungan $\mathrm{C}$ dan $\mathrm{P}$ tertinggi dibandingkan dengan dosis 0,5 g $500 \mathrm{~g}^{-1}$ tanah. Menurut Balitanah (2009), penambahan kompos ke dalam tanah mampu meningkatkan unsur hara makro ke dalam tanah.

\section{Hubungan dan pengaruh Corganik dengan $\mathrm{pH}$ tanah}

Berdasarkan uji korelasi yang telah dilakukan dapat dilihat bahwa antara $\mathrm{C}$ organik dengan $\mathrm{pH}$ $\mathrm{H}_{2} \mathrm{O}$ menunjukkan korelasi negatif signifikan ( $\mathrm{r}$ $\left.=-0,74^{*}\right)$. Korelasi antara kandungan $\mathrm{C}$ organik dengan $\mathrm{pH}(\mathrm{KCl})$ juga signifikan negatif $(\mathrm{r}=$ $\left.0,57^{*}\right)$, dan hubungan antara kandungan $\mathrm{C}$ organik dengan $\Delta \mathrm{pH}$ menunjukkan korelasi positif signifikan $(\mathrm{r}=0,84)$. Hubungan antara kandungan $\mathrm{C}$ organik dengan $\mathrm{pH}$ tanah disajikan pada (Gambar 1).
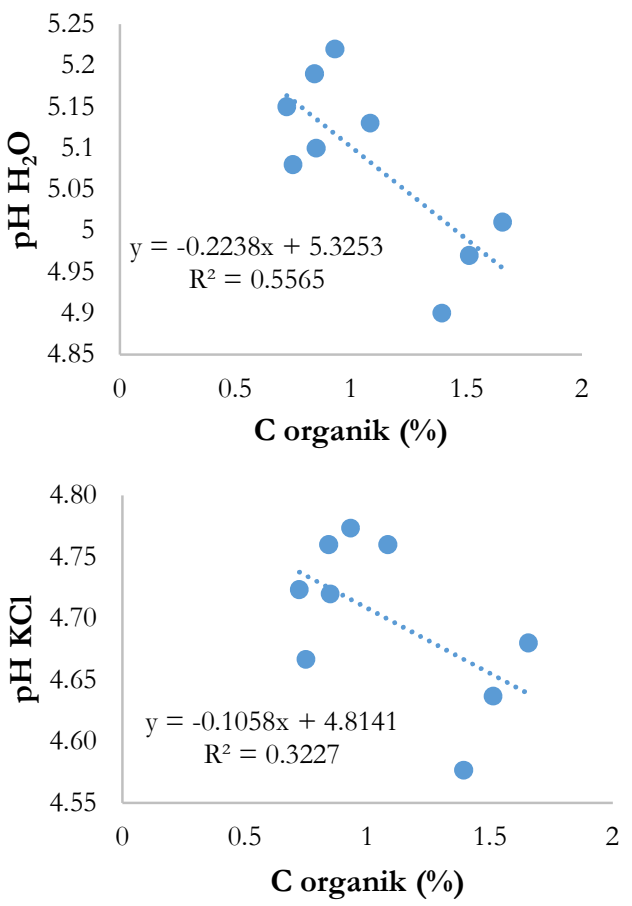

(A)

(B)

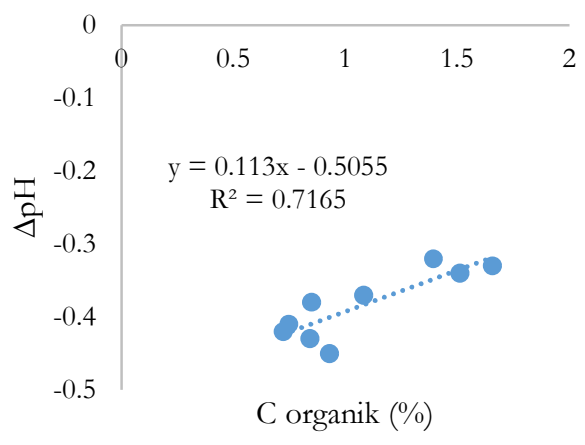

(C)

Gambar 1. Pengaruh kandungan $\mathrm{C}$ - organik dengan $\mathrm{pH} \mathrm{H} \mathrm{H}_{2} \mathrm{O}(\mathrm{A}) \mathrm{pH} \mathrm{KCl}(\mathrm{B}) \Delta \mathrm{pH}(\mathrm{C})$ pada pengamatan $18 \mathrm{MSI}$.

Model regresi (Gambar 1) menunjukkan bahwa nilai $\mathrm{R}^{2}$ antara $\mathrm{C}$ organik dengan $\mathrm{pH} \mathrm{H}_{2} \mathrm{O}$ adalah 0,56 atau $56 \%$ yang berarti nilai $\mathrm{C}$ organik mempengaruhi penurunan nilai $\mathrm{pH} \mathrm{H}_{2} \mathrm{O}$ secara 


\section{Jurnal Tanah dan Sumberdaya Lahan Vol 8 No 2: 505-514, 2021 e-ISSN:2549-9793, doi: 10.21776/ub.jts1.2021.008.2.21}

signifikan sebesar 56\%, sedangkan 34\% dipengaruhi oleh faktor lain. Nilai $\mathrm{R}^{2}$ antara C organik dengan $\mathrm{pH} \mathrm{KCl}$ adalah 0,32 atau $32 \%$ yang berarti nilai $\mathrm{C}$ organik mempengaruhi penurunan nilai $\mathrm{pH} \mathrm{KCl}$ sebesar 32\%, sedangkan 68\% dipengaruhi oleh faktor lain. Nilai $\mathrm{R}^{2}$ antara $\mathrm{C}$ organik dengan $\Delta \mathrm{pH}$ adalah 0,72 atau $72 \%$ yang berarti nilai $\mathrm{C}$ organik mempengaruhi peningkatan $\Delta \mathrm{pH}$ secara signifikan sebesar $72 \%$, sedangkan $28 \%$ disebabkan oleh faktor lainnya. Model regresi (Gambar 1) menunjukkan apabila $\mathrm{C}$ organik tanah meningkat $1 \%$ akan menurunkan $\mathrm{pH} \mathrm{H}_{2} \mathrm{O}$ sebesar 0,22. dan 0,11 pada pH KCl. Model regresi (gambar 1) juga menunjukkan apabila nilai $\mathrm{C}$ organik meningkat $1 \%$ akan menaikan $\Delta \mathrm{pH}$ sebesar 0,11 . Hal tersebut kurang sesuai dengan pernyataan Nariratih et al. (2013), yang menyatakan bahwa kandungan $\mathrm{C}$ organik yang tinggi pada tanah dapat meningkatkan kemampuan dalam mengikat $\mathrm{Al}^{3+}$ sehingga $\mathrm{pH}$ $\mathrm{H}_{2} \mathrm{O}$ pada tanah dapat meningkat. Menurut Leiwakabessy dan Sutandi (2003), penurunan $\mathrm{pH}$ menjadi asam berkaitan dengan amonium (bersifat asam), pada awal meningkatkan $\mathrm{pH}$ namun seiring berjalannya waktu terjadi penurunan jumlah amonium dan peningkatan jumlah nitrat. (bersifat asam).

\section{Hubungan dan pengaruh Corganik dengan fosfor tanah}

Berdasarkan uji korelasi yang telah dilakukan dapat dilihat bahwa $C$ organik dengan P tersedia dan P total memiliki hubungan yang sangat kuat. Nilai korelasi antara C organik dengan P tersedia ataupun $\mathrm{P}$ total sama-sama memiliki nilai $\mathrm{r}=0,96$, yang artinya $\mathrm{C}$ organik memiliki hubungan yang sangat kuat dengan $\mathrm{P}$ tersedia maupun $\mathrm{P}$ total. Pengaruh $\mathrm{C}$ organik dengan $\mathrm{P}$ total dan P tersedia disajikan dalam (Gambar 2). Model regresi (Gambar 2) menunjukkan bahwa nilai R2 pada $\mathrm{P}$ tersedia adalah 0,92 atau $92 \%$ dan pada $P$ total memiliki nilai sebesar 0,93 atau $93 \%$, yang berarti nilai C organik mempengaruhi peningkatan $\mathrm{P}$ tersedia sangat signifikan sebesar $92 \%$, sedangkan $8 \%$ disebabkan oleh faktor lain. Model regresi (Gambar 2) menunjukkan C organik mempengaruhi penigkatan $\mathrm{P}$ total sangat signifikan sebesar $93 \%$, sedangkan $7 \%$ dipengaruhi oleh faktor lain. Model regresi (Gambar 2) menunjukkan jika kandungan C organik meningkat $1 \%$ akan meningkatkan $\mathrm{P}$ tersedia sebesar 5,15 ppm dan sebesar 415,97 ppm untuk P total. Peningkatan ini sisebabkan karna penambahan bahan organik ke dalam tanah.
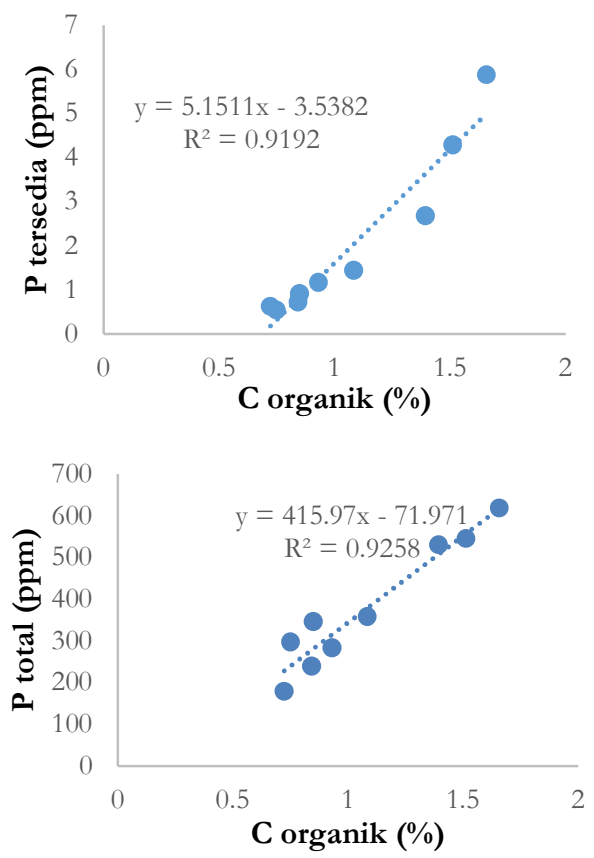

Gambar 2. Pengaruh kandungan C organik dengan kandungan $\mathrm{P}$ tersedia, dan $\mathrm{P}$ total di dalam tanah (B) pada pengamatan $18 \mathrm{MSI}$.

Menurut Karnilawati et al. (2013), hasil dekomposisi bahan organik dapat berpengaruh terhadap kelarutan P di dalam tanah sehingga jumlah unsur P di dalam tanah dapat meningkat. Konsentrasi asam-asam organik yang dihasilkan melalui proses dekomposisi dari bahan organik dapat melepaskan P yang diikat oleh fraksi amorf yang berakibat meningkatkan $\mathrm{P}$ tersedia dalam tanah (Winarso, 2005).

\section{Hubungan dan pengaruh ketersediaan $P$ dan total P dalam tanah}

Hasil korelasi menunjukkan bahwa P tersedia dan P total memiliki hubungan yang sangat kuat. Nilai korelasi antara $\mathrm{P}$ tersedia dengan $\mathrm{P}$ total sebesar $\mathrm{r}=0,92$, yang menandakan antara $\mathrm{P}$ tersedia dengan $\mathrm{P}$ total memiliki hubungan yang sangat kuat. Pengaruh C organik dengan P total dan P tersedia disajikan dalam Gambar 3. 


\section{Jurnal Tanah dan Sumberdaya Lahan Vol 8 No 2: 505-514, 2021 e-ISSN:2549-9793, doi: 10.21776/ub.jts1.2021.008.2.21}

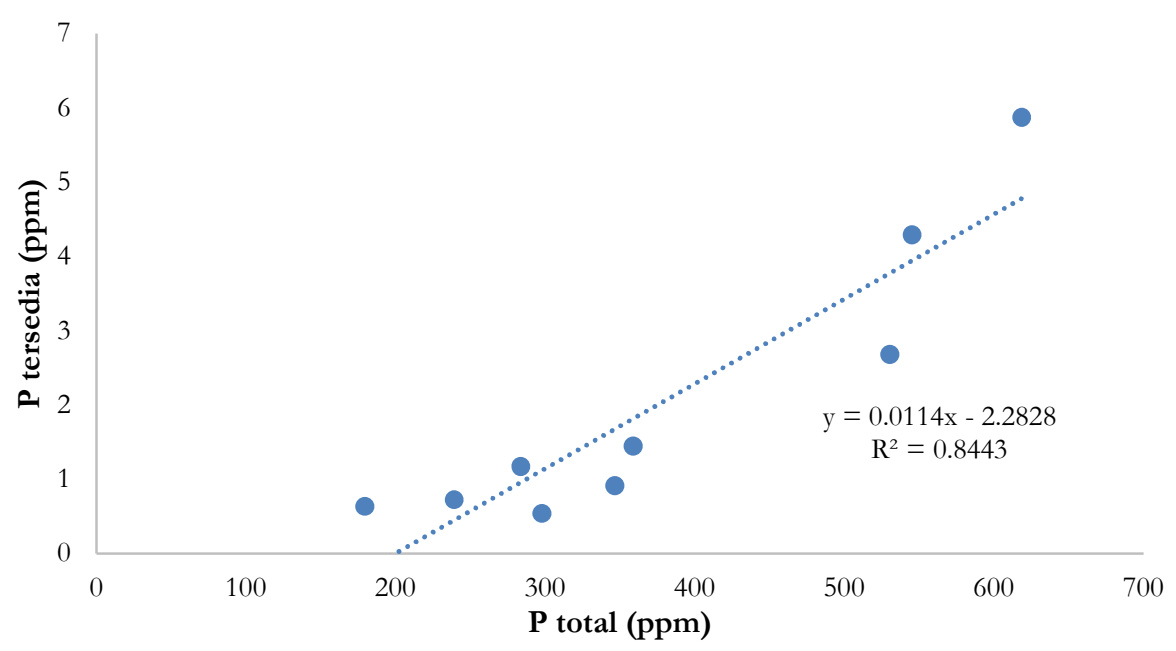

Gambar 3. Pengaruh kandungan fosfor total dalam tanah dengan kandungan ketersediaan fosfor dalam tanah pada pengamatan 18 MSI.

Model regresi (Gambar 3) menunjukkan nilai $\mathrm{R}^{2}$ sebesar 0,84 atau $84 \%$ yang artinya nilai $\mathrm{P}$ total mempengaruhi peningkatan $\mathrm{P}$ tersedia sangat signifikan sebesar $84 \%$, sedangkan $16 \%$ disebakan oleh faktor lain. Model regresi (Gambar 3) menunjukkan apabila kandungan P total naik 1 ppm maka akan meningkatkan nilai $\mathrm{P}$ tersedia sebesar $0,011 \mathrm{ppm}$. Nilai P total yang lebih tinggi daripada $\mathrm{P}$ tersedia disebabkan karna dalam pengekstrakan $\mathrm{P}$ total tidak hanya bentuk $\mathrm{P}$ yang cepat tersedia saja yang diteliti, namun bentuk organik $\mathrm{P}$ yang "sedang hingga lambat" tersedia ikut diteliti. Widjaja-Adhi dan Sudjadi (1987), menjelaskan bentuk Ca-P, Fe-P, dan Al-P merupakan bentuk $\mathrm{P}$ yang cepat tersedia, sedangkan organik-P dan residu-P sedang hingga lambat tersedia bagi tanaman. Bentuk P yang lambat tersedia merupakan P cadangan yang sangat penting dalam mempertahankan konsentrasi bentuk $\mathrm{P}$ cepat tersedia karena bentuk-bentuk $\mathrm{P}$ tersebut berada dalam reaksi keseimbangan dalam tanah.

\section{Kesimpulan}

Dosis anjuran kompos kotoran kambing berbeda pada setiap kedalaman tanah tertentu. Dosis kompos kotoran kambing yang dianjurkan pada kedalaman tanah tertentu mampu meningkatkan $\mathrm{pH}, \mathrm{C}$ organik, $\mathrm{P}$ tersedia dan $\mathrm{P}$ total dalam tanah. Masing-masing dosis yang dianjurkan pada kedalaman tanah $0-20 \mathrm{~cm}$,
20-40 cm dan 40-60 cm yaitu sebesar $1 \mathrm{~g} 500 \mathrm{~g}$ 1 tanah yang masing-masing setara dengan 5,64 t ha-1, 5,52 $\mathrm{tha}^{-1}$ dan 5,36 $\mathrm{tha}^{-1}$.

\section{Ucapan Terima Kasih}

Penulis mengucapkan terimakasih kepada staf Kebun Kopi Bangelan, Kecamatan Wonosari, Kabupaten Malang, atas bantuannya dalam pengambilan sampel tanah utnuk penelitian ini.

\section{Daftar Pustaka}

Amran, M.B., Sari, N.K.E., Setyorini, D.A., Wahyu, Y., Widiani, D. dan Irnameria, D. 2015. Analisis Kualitas Tanah Pantai Sawarna Kabupaten Lebak Provinsi Banten. Prosiding Simposium Nasional Inovasi dan Pembelajaran Sains 2015.

Awodun, M.A. 2007. Effect of goat manure and urea fertilizer on soil, growth, and yield of Okra (Abelmoschus esculentus L. Moench). Journal of Agricultural Research 2(7): 632-636

Aziz, A., Muyassir, M. dan Bakhtiar, B. 2012. Perbedaan jarak tanam dan dosis pupuk kandang terhadap sifat kimia tanah dan hasil padi sawah. Jurnal Manajemen Sumberdaya Lahan 1(2): 120125.

Balitanah (Balai Penelitian Tanah). 2009. Petunjuk Teknis Analisis Kimia Tanah, Tanaman, Air, dan Pupuk. Balai Penelitian Tanah. Bogor. Hal : 225

Damanik, M.M.B., Hasibuan, B.E., Fauzi., Sarifuddin. dan Hanum, H. 2010. Kesuburan Tanah dan Pemupukan. Universitas Sumatera Utara. Medan. 


\section{Jurnal Tanah dan Sumberdaya Lahan Vol 8 No 2: 505-514, 2021 e-ISSN:2549-9793, doi: 10.21776/ub.jts1.2021.008.2.21}

Hakim, N.M., Nyakpa, N., Lubis, A.M., Nugroho, S.G., Saul, M.R., Diha, M.A., Hong, G.B. dan Bailey, H.H. 1986. Dasar-dasar Ilmu Tanah. Presindo, Jakarta.

Hanafiah K.A. 2012. Dasar-Dasar Ilmu Tanah. Cetakan Ke-5. Jakarta: PT Raja Grafindo Persada: 36

Hong, T.K. 2008. Principles of Soil Chemistry. 2nd Edition. Marcel Dekker Inc. New york. P. 362.

Ichriani, G.I., Atikah, T.A., Zubaidah, S. dan Fatmawati, R. 2013. Kompos tandan kosong kelapa sawit untuk perbaikan daya simpan air tanah kapasitas lapangan. Jurnal Penelitian Universitas Palangkaraya.

Irawan, A., Jufri, Y. dan Zuraida. 2016. pengaruh pemberian bahan organik terhadap perubahan sifat kimia Andisol, pertumbuhan dan produksi gandum (Triticum eastivum L.). Jurnal Kawista 1(1):1-9.

Karnilawati, Sufardi. dan Syakur. 2013. Phosfat Tersedia, serapannya serta pertumbuhan jagung (Zea mays L) akibat amelioran dan mikoriza pada Andisol. Jurnal Manajemen Sumber Daya Lahan 3(2): 231-239.

Leiwakabessy, F.M. dan Sutandi, A. 2003. Pupuk dan Pemupukan. Jurusan Tanah, Fakultas Pertanian, Institut Pertanian Bogor. Bogor. 208 hal.

Masjkur, M. 2007. Analisis biplot status kesuburan tanah. Forum Statistika dan Komputasi (12) 1: 24-29.

Mukhlis., Sariffudin. dan Hanum, H. 2011. Kimia Tanah Teori dan Aplikasi. Universitas Sumatera Utara Press. Medan.

Mupondi, L.T., Mnkeni, P.N.S. and Brutsch, M.O. 2006. The effects of goat manure, sewage sludge and effective microorganisms on the composting of pine bark. Compost Science dan Utilization 14(3): 201-210.

Muyassir, Sufardi, dan Saputra, I. 2012. Perubahan sifat fisika Inceptisol akibat perbedaan jenis dan dosis pupuk organik. Lentera 12 (1): 1-8.

Nariratih I., Damanik, B., Majid, M. dan Sitanggang, G. 2013. Ketersediaan nitrogen pada tiga jenis tanah akibat pemberian tiga bahan organik dan serapannya pada tanaman jagung. Jurnal Online Agroekoteknologi 3(1): 479-488.

Pratiwi, I.G.AP., Atmaja, I.W.D. dan Soniari, N.N. 2013. Analisis kualitas kompos limbah persawahan dengan MOL sebagai dekomposer. Jurnal Agroekoteknologi Tropika 4(2): 195 - 203.

Putra B.P. dan Nuraini, Y. 2017. Kajian inkubasi berbagai dosis pupuk cair fermentasi lendir cacing tanah (Lumbricus rubellus) terhadap fosfor, $\mathrm{C}$ organik dan $\mathrm{pH}$ pada Inceptisol. Jurnal Tanah dan Sumber Daya Lahan 4(2): 521-524.
Rosmarkan, A. dan Yuwono, N.W. 2002. Ilmu Kesuburan Tanah. Kanisius, Yogyakarta. p.156180.

Setyorini, D., Saraswati, R. dan Anwar, E.K. 2006. Pupuk Organik dan Pupuk Hayati. Balai Besar Litbang Sumberdaya Lahan Pertanian. Badan Penelitian Pengembangan Pertanian, Bogor.

Sipahutar, A.H., Marbun, P. dan Fauzi. 2014. Kajian C organik, $\mathrm{N}$ dan $\mathrm{p}$ humitropepts pada ketinggian tempat yang berbeda di Kecamatan Lintong Nihuta. Jurnal Online Agroekoteknologi (2)4: 1332- 1338.

Sismiyanti, Hermansah, Yulnafatmawita. 2018. Klasifikasi beberapa sumber bahan organik. Jurnal Solum 17(1): 8-16.

Sudirja, R., Solihin, M.A. dan Rosniawaty, S. 2006. Pengaruh kompos kulit buah kakao dan kascing terhadap perbaikan beberapa sifat kimia Fluventic Eutrudepts. Jurnal Fakultas Pertanian. Universitas Padjadjaran.

Suharta, N. 2007. Sifat dan karakteristik tanah dari batuan sedimen masam di Provinsi Kalimantan Barat serta implikasinya terhadap pengelolaan lahan. Jurnal Tanah dan Iklim 25: 11-26.

Utami, S.N.H., Purwanto, B.H. dan Putra, R.C. 2013. Pengaruh Pupuk Kandang Kambing dan Azolla Terhadap Beberapa Sifat Kimia Tanah dan Serapan Padi di Sawah Organik Sambirejo, Sragen. Dalam Kumpulan Makalah Seminar Nasional Solusi Mewujudkan Produksi Pangan Yang Aman dan Ramah Lingkungan Serta Meningkatkan Pendapatan Petani. Jurusan Tanah, Fakultas Pertanian UGM. Yogyakarta.

Widjaja-Adhi, I P.G. dan M. Sudjadi. 1987. Status dan kelakuan fosfat tanah-tanah di Indonesia. Hlm 223-242 Dalam Prosiding Lokakarya Nasional Penggunaan Pupuk Fosfat. Cipanas, 29 Juni-2 Juli 1987. Pusat Penelitian Tanah, Bogor.

Widodo, K.H. dan Kusuma, Z. 2018. Pengaruh kompos terhadap sifat fisik tanah dan pertumbuhan tanaman jagung di Inceptisol. Jurnal Tanah dan Sumberdaya Lahan 5(2) : 959967.

Winarso. 2005. Pengaruh Pemberian Kompos dan Masa Inkubasi terhadap Ketersediaan P pada Andisol yang diberi Fosfat Alam. Fakultas Pertanian USU, Medan. 